\title{
EBV-Related Diffuse Large B-Cell Lymphoma in a Patient with Angioimmunoblastic T-Cell Lymphoma
}

\author{
Anjiyoimmünoblastik T-Hücreli Lenfomaya Eşlik Eden EBV-Ilişkili Diffüz Büyük \\ B-Hücreli Lenfoma
}

(D) Cem Şimşek¹, (D) Başak Bostankolu1, (D) Ece Özoğul2, (D) Arzu Sağlam Ayhan², (D) Ayşegül Üner², (D) Yahya Büyükaşık³

${ }^{1}$ Hacettepe University Faculty of Medicine, Department of Internal Medicine, Ankara, Turkey

${ }^{2}$ Hacettepe University Faculty of Medicine, Department of Pathology, Ankara, Turkey

${ }^{3}$ Hacettepe University Faculty of Medicine, Division of Hematology, Ankara, Turkey

To the Editor,

Angioimmunoblastic T-cell lymphoma (AITL) is a common subtype of peripheral T-cell lymphoma, accounting for approximately one-fifth of cases [1]. Epstein-Barr virus (EBV)positive $B$ cells are present in the tumor tissue in most cases [2]. Twenty-five cases of EBV-associated B-cell lymphomas in AITL patients have been reported in the literature $[1,3,4,5,6,7,8,9,10$, $11,12,13,14,15]$; herein, we report the $26^{\text {th }}$ case.

A 68-year-old female patient presented with B symptoms, multiple lymphadenopathies, and hepatosplenomegaly. Her laboratory studies were unremarkable except for normocytic anemia, eosinophilia, and increased lactate dehydrogenase. Her HIV serology was negative. Lymph node biopsy showed total effacement of the lymph node architecture with a polymorphic infiltrate composed of small to medium-sized lymphocytes, eosinophils, and occasional immunoblasts in a background of vascular proliferation (Figures $1 \mathrm{~A}$ and 1B). Neoplastic cells were positive for CD3, CD4, PD1, and CD2. There was an extensive growth of follicular dendritic

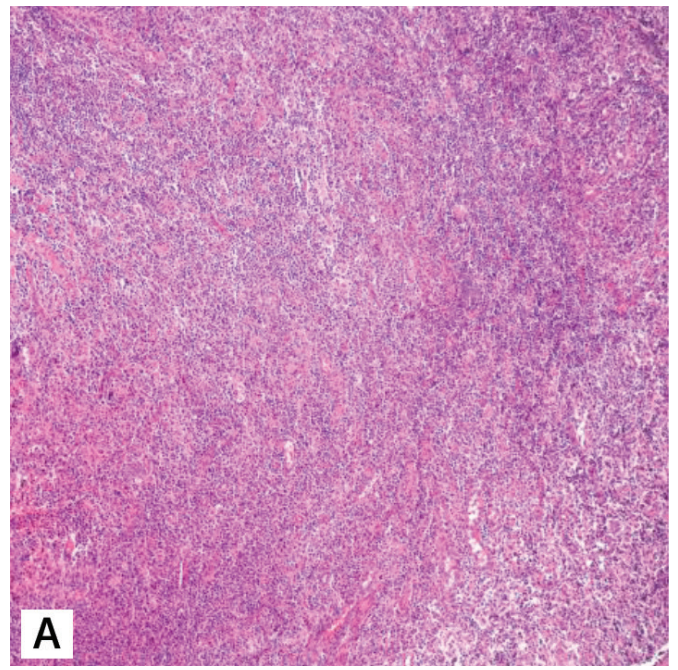

meshwork extending beyond the germinal centers. Large immunoblastic cells were scattered and positive for CD20. There were only occasional scattered LMP-1-positive blasts. However, T-cell receptor clonality analysis revealed a single prominent band with Tvy-5J17 primers observed initially. In a subsequent biopsy, a sharp band with fr22 primers was observed. The morphologic and immunophenotypic features of the lymphoid proliferation were consistent with AITL. Six cycles of a CVP regimen (cyclophosphamide, vincristine, and prednisolone) were administered in 6 months. Doxorubicin or any other anthracycline was not administered due to associated cardiac morbidities. Post-treatment evaluation imaging showed radiological remission. However, nearly 1 month later, and 7 months after the initial diagnosis, she presented with multiple pruritic erythematous plaques on her arms and back. B symptoms had also returned. A biopsy from the largest lesion on her forearm showed infiltration of the dermis and subcutaneous tissue with large pleomorphic cells. Subsequent B-cell lymphoma cells that developed in the background of angioimmunoblastic lymphoma were positive

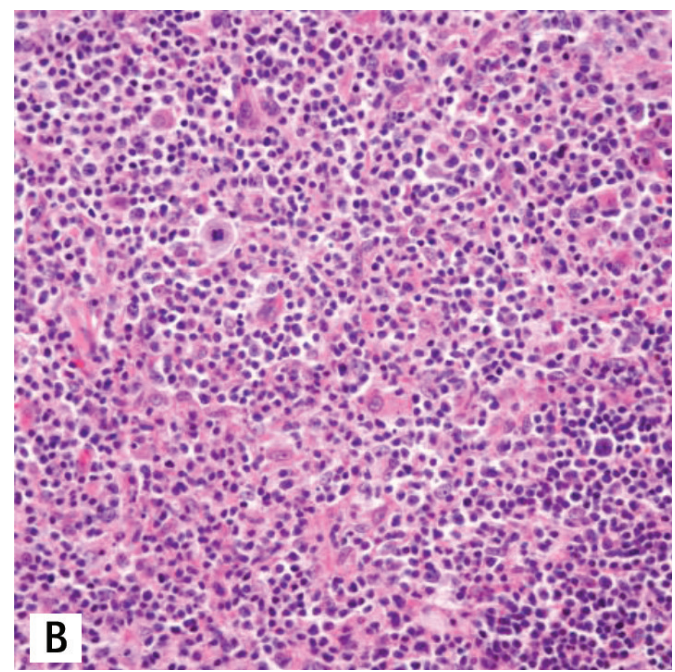

Figure 1. A, B) Cervical lymph node biopsy showing angoimmunoblastic T-cell lymphoma. Effacement of lymph node architecture, infiltrate of small to-medium sized lymphocytes, eosinophils, and occasional immunoblasts in a background of vascular proliferation consistent with angioimmunoblastic T-cell lymphoma. 


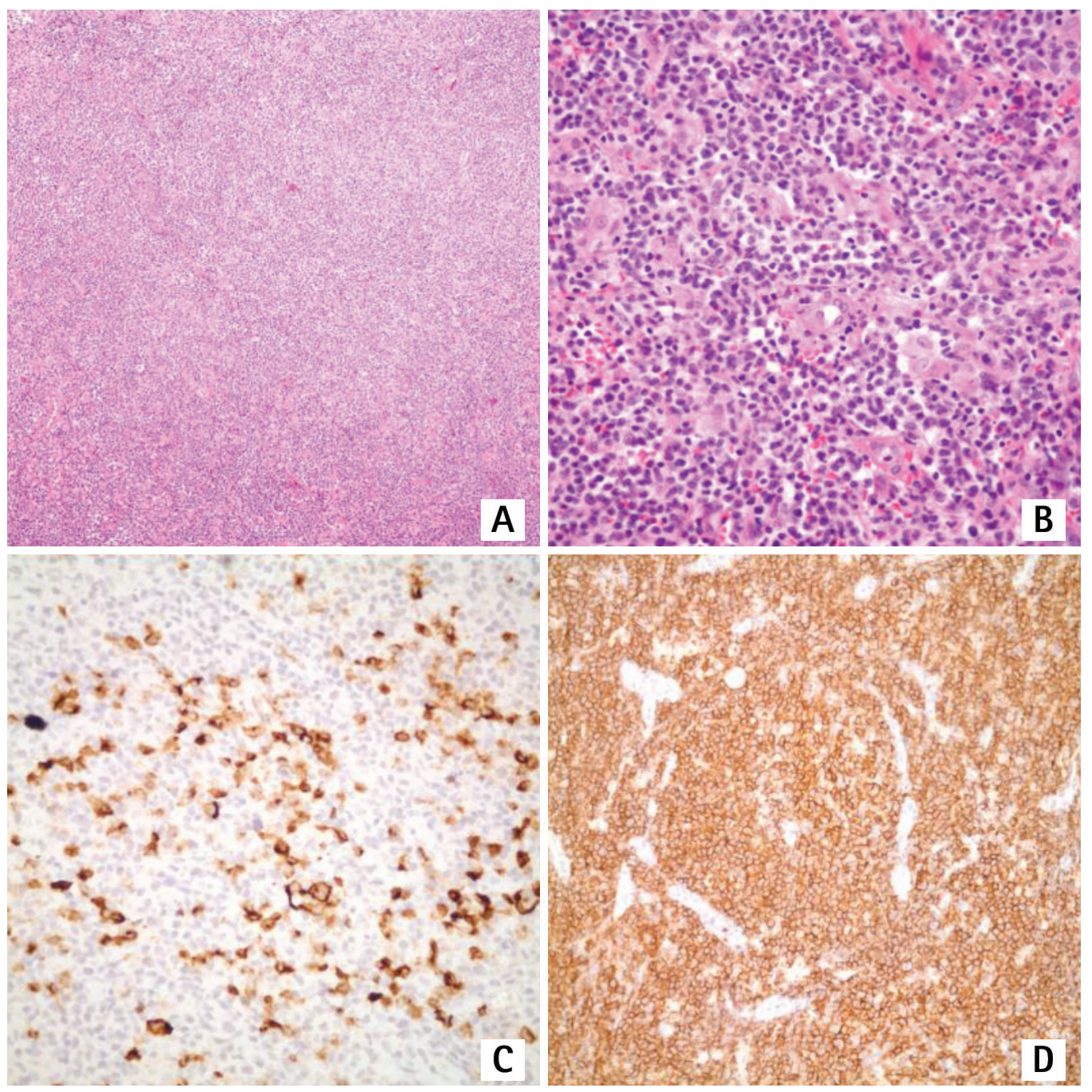

Figure 2. Biopsy from cutaneous lesion: A, B) infiltration of the dermis and subcutaneous tissue with large pleomorphic cells; C) with CD20 positivity; D) with LMP-1 positivity.

for CD20, LMP-1, and EBER (Figure 2). The diagnosis was EBVrelated diffuse large B-cell lymphoma (DLBCL) secondary to AITL. Control radiological examinations and/or bone marrow biopsies were not performed at that time. ICE (etoposide, iphosphamide, mesna, carboplatin) was started and 3 cycles were completed [16]. Rituximab (375 $\mathrm{mg} / \mathrm{m}^{2}$ on day 1) was added to the protocol after the first cycle. A later control biopsy from skin lesions showed residual B-cell neoplasia. Control imaging also showed widespread lymphadenopathies in the neck, thorax, and abdomen. She was monitored closely without further cytotoxic treatment since she had poor performance status. The patient died of sepsis, with an overall survival of 14 months.

Secondary B-cell lymphoma may complicate AITL and has a poor prognosis. Only 3 of the previously reported 25 patients were described to have an overall survival longer than 12 months. Clinicians should be alerted by new-onset symptoms or lesions in a lymphoma patient, and suspicious lesions should be biopsied. The optimal treatment for either AITL or secondary DLBCL remains undefined.

Could the patient have had two different lymphomas (i.e. simultaneous or composite lymphomas) at the first presentation? It is impossible to exclude the possibility that she had additional EBV-related DLBCL in some of the multiple lymphadenopathies, with enlarged spleen and liver at presentation. Even so, the message to be taken from the association of AITL and EBV-related DLBCL (either simultaneous/composite or sequential) is the same: AITL is frequently EBV-positive and this positivity may result in EBVpositive DLBCL. Therefore, clinicians should be aware of this possibility.

Keywords: Angioimmunoblastic T-cell lymphoma, Secondary Iymphoma, EBV-related lymphoma, Cutaneous lymphoma

Anahtar Sözcükler: Anjiyoimmünoblastik T hücreli lenfoma, İkincil lenfoma, EBV-ilişkili lenfoma, Deri lenfomaları 
Conflict of Interest: The authors of this paper have no conflicts of interest, including specific financial interests, relationships, and/or affiliations relevant to the subject matter or materials included.

\section{References}

1. Zettl $A$, Lee $S S$, Rüdiger $T$, Starostik $P$, Marino $M$, Kirchner $T$, Ott $M$, Müller-Hermelink HK, Ott G. Epstein-Barr virus-associated B-cell lymphoproliferative disorders in angioimmunoblastic T-cell lymphoma and peripheral T-cell lymphoma, unspecified. Am J Clin Pathol 2002;117:368379.

2. Zhou Y, Attygalle AD, Chuang SS, Diss T, Ye H, Liu H, Hamoudi RA, Munson $\mathrm{P}$, Bacon CM, Dogan A, Du MQ. Angioimmunoblastic T-cell lymphoma: histological progression associates with EBV and HHV6B viral load. $\mathrm{Br} J$ Haematol 2007;138:44-53.

3. Yang QX, Pei XJ, Tian XY, Li Y, Li Z. Secondary cutaneous EpsteinBarr virus-associated diffuse large B-cell lymphoma in a patient with angioimmunoblastic T-cell lymphoma: a case report and review of literature. Diagn Pathol 2012;7:7.

4. Abruzzo LV, Schmidt K, Weiss LM, Jaffe ES, Medeiros L, Sander CA, Raffeld M. B-Cell lymphoma after angioimmunoblastic lymphadenopathy - a case with oligoclonal gene rearrangements associated with Epstein-Barr virus. Blood 1993;82:241-246.

5. Park S, Noguera ME, Brière J, Feuillard J, Cayuela JM, Sigaux F, Brice P. Successful rituximab treatment of an EBV-related lymphoproliferative disease arising after autologous transplantation for angioimmunoblastic T-cell lymphoma. Hematol J 2002;3:317-320.

6. Xu Y, McKenna RW, Hoang MP, Collins RH, Kroft SH. Composite angioimmunoblastic T-cell lymphoma and diffuse large B-cell lymphoma - A case report and review of the literature. Am J Clin Pathol 2002;118:848854.

7. Hawley RC, Cankovic M, Zarbo RJ. Angioimmunoblastic T-cell lymphoma with supervening Epstein-Barr virus-associated large B-cell lymphoma. Arch Pathol Lab Med 2006;130:1707-1711.
8. Attygalle AD, Kyriakou C, Dupuis J, Grogg KL, Diss TC, Wotherspoon AC, Chuang SS, Cabeçadas J, Isaacson PG, Du MQ, Gaulard P, Dogan A. Histologic evolution of angioimmunoblastic T-cell lymphoma in consecutive biopsies: clinical correlation and insights into natural history and disease progression. Am J Surg Pathol 2007;31:1077-1088.

9. Willenbrock K, Braeuninger A, Hansmann ML. Frequent occurrence of B-cell lymphomas in angioimmunoblastic T-cell lymphoma and proliferation of Epstein-Barr virus-infected cells in early cases. Br J Haematol 2007;138:733739.

10. Weisel KC, Weidmann E, Anagnostopoulos I, Kanz L, Pezzutto A, Subklewe M. Epstein-Barr virus-associated B-cell lymphoma secondary to FCD-C therapy in patients with peripheral T-cell lymphoma. Int J Hematol 2008;88:434440.

11. Skugor ND, Perić Z, Vrhovac R, Radić-Kristo D, Kardum-Skelin I, Jaksić B. Diffuse large B-cell lymphoma in patient after treatment of angioimmunoblastic T-cell lymphoma. Coll Antropol 2010;34:241-245.

12. Takahashi $T$, Maruyama $R$, Mishima $S$, Inoue $M$, Kawakami $K$, Onishi $C$, Miyake T, Tanaka J, Nabika T, Ishikura H. Small bowel perforation caused by Epstein-Barr virus-associated B cell lymphoma in a patient with angioimmunoblastic T-cell lymphoma. J Clin Exp Hematop 2010;50:59-63.

13. Huang J, Zhang PH, Gao YH, Qiu LG. Sequential development of diffuse large B-cell lymphoma in a patient with angioimmunoblastic T-cell lymphoma. Diagn Cytopathol 2012;40:346-351.

14. Smeltzer JP, Viswanatha DS, Habermann TM, Patnaik MM. Secondary Epstein-Barr virus associated lymphoproliferative disorder developing in a patient with angioimmunoblastic T cell lymphoma on vorinostat. Am J Hematol 2012;87:927-928.

15. Lee MH, Moon IJ, Lee WJ, Won CH, Chang SE, Choi JH, Lee MW. A case of cutaneous Epstein-Barr virus-associated diffuse large B-cell lymphoma in an angioimmunoblastic T-cell lymphoma. Ann Dermatol 2016;28:789-791.

16. Moskowitz $\mathrm{CH}$, Bertino JR, Glassman JR, Hedrick EE, Hunte $\mathrm{S}$, Coady-Lyons N, Agus DB, Goy A, Jurcic J, Noy A, O'Brien J, Portlock CS, Straus DS, Childs B, Frank R, Yahalom J, Filippa D, Louie D, Nimer SD, Zelenetz AD. Ifosfamide, carboplatin, and etoposide: a highly effective cytoreduction and peripheralblood progenitor-cell mobilization regimen for transplant-eligible patients with non-Hodgkin's lymphoma. J Clin Oncol 1999;17:3776-3785.

\begin{tabular}{rr}
\hline$\square$ & Received/Geliş tarihi: January 13, 2018 \\
Hacettepe University Faculty of Medicine, Department of Internal Medicine, Ankara, Turkey & Accepted/Kabul tarihi: August 01, 2018 \\
Phone : +90 5342964684 & \\
E-mail : cemsimsek111@gmail.com ORCID-ID: orcid.org/0000-0002-7037-5233 & D0I: 10.4274/tjh.galenos.2018.2018.0023 \\
\hline
\end{tabular}

